\title{
EDITORIAL
}

\section{Metamorfoze ale potenţialităţilor educative ale familiei în societatea modernă}

Dorin OPRIȘ*

Odată cu dezvoltarea comunităţilor umane, o parte dintre sarcinile tot mai numeroase şi mai complexe ale educării copiilor au început să fie preluate de către acestea. Instituţia familiei şi-a asumat în continuare sarcina de modelare a copiilor din perspectiva propriului set de valori, într-un context comunitar tot mai eterogen.

Schimbările majore care au intervenit în viaţa familiei şi implicit în posibilităţile de realizare a funcţiei educaţionale au fost determinate de debutul industrializării în Europa de Vest. Ceea ce astăzi numim Revoluţia industrială, care a debutat în Anglia la sfârşitul secolului al XVIII-lea, reprezintă în mare măsură perioada care a condus la disoluţia modelului tradiţional de familie. Deşi momentul este considerat în societatea europeană ca unul de mare progres, prin faptul că a mutat în mare parte forţa de muncă din arealul casei în zone adesea foarte îndepărtate,

* Pr. conf. univ. dr. habil., Departamentul pentru Pregătirea Personalului Didactic, Universitatea „1 Decembrie 1918” din Alba Iulia; Școala Doctorală „Didactica”, Universitatea „Babeș-Bolyai” din Cluj-Napoca. 
constituie momentul de start pentru actualele ipostaze pe care le cunoaşte familia şi educaţia din cadrul acesteia. Din punct de vedere material, creşterea numărului de locuri de muncă în diferite activități din agricultură sau din comerţ a făcut să se diminueze considerabil preocuparea membrilor familiei pentru a obţine împreună valorile materiale necesare traiului. Ceea ce anterior se constituia într-un demers comun, într-un efort cu puternice componente social-economice, dar şi formative, a încetat să mai reprezinte un factor de coeziune.

Schimbarea, departe de a se constitui într-un simplu motor al creşterii economice sau al dezvoltării societăţii prin accesul la informare şi formare în contexte noi, a generat scăderea accelerată a posibilităţilor de intervenţie în plan educaţional-familial a părinţilor. Creşterea măsurii în care copiii au început să dobândească de la părinţi abilităţi noi în domeniile cerute de piaţa forţei de muncă, în special după ce unul dintre părinţi a început să lucreze în afara familiei, de obicei de la tată, a condus la maturizarea mult mai rapidă şi adesea forţată, necorelată cu vârsta copiilor, cu dezvoltarea fizică şi emoţională a acestora. Scăderea timpului în care copiii au parcurs etapele de dezvoltare personală din primii ani ai vieţii, inclusiv anii de educaţie acasă, alături de părinţi şi de ceilalţi membrii ai familiei, nu a putut fi compensată de către adulţii din mediul familial prin componente formative noi, relevante. Rămase singure acasă, mamele au înregistrat tot mai multe dificultăţi în efortul de a gestiona eficient numeroasele şi tot mai dificilele sarcini legate de educaţia copiilor. Acest fapt a făcut ca realizările în plan material să fie puternic umbrite de pierderea în planul dezvoltării morale a copiilor, al stabilirii şi respectării în familie a unor norme educaţionale eficiente.

Perioada contemporană, marcată de noile curente culturale şi sociale aduse de postmodernism, a accentuat tendinţele etapelor anterioare. Familia continuă paşii în delegarea către instituţia şcolară a funcţiei sale educative, cu creşteri semnificative în procesul dezvoltării intelectuale a copiilor, dar şi cu tot mai numeroase dificultăţi în formarea de atitudini şi valori în 
Metamorfoze ale potenţialităţilor educative ale familiei în societatea modernă

concordanţă cu propriul model existenţial, marcat în principal de perspectiva privind valoarea şi destinul omului.

Numărul de față al revistei „Altarul Reîntregirii” (3/2020) grupează, sub genericul Familie și educație în societatea postmodernă, o serie de articole cu caracter puternic interdisciplinar, care includ cercetări prin care este analizată posibilitatea de intervenţie educativă a familiei. Cadre didactice şi tineri cercetători, din diferite universităţi din România şi din Republica Moldova, caută să identifice, din perspectiva teologiei, a psihologiei şi a ştiinţelor educaţiei, soluţii pentru susţinerea familiei în redescoperirea posibilităţilor sale de intervenţie educaţională.

0880

\section{Bibliografie}

1. Cope, Henry F., Religious Education in the Family, Library of Alexandria, 2012.

2.OPRIŞ, Dorin, Educaţie şi religie. Analize, reflecţii, provocări, ClujNapoca, Presa Universitară Clujeană, 2019.

3. VLĂSCEANU, Lazăr, Sociologie și modernitate. Tranziții spre modernitatea reflexivă, Iaşi, Editura Polirom, 2007. 